\title{
NOM removal technologies - Norwegian experiences
}

\author{
H. Ødegaard ${ }^{1}$, S. Østerhus ${ }^{2}$, E. Melin ${ }^{2}$, and B. Eikebrokk ${ }^{2}$ \\ ${ }^{1}$ Department of Hydraulic and Environmental Engineering, Norwegian University of \\ Science and Technology (NTNU), 7491 Trondheim, Norway \\ ${ }^{2}$ Water and Environment, SINTEF, 7491 Trondheim, Norway \\ Received: 15 July 2009 - Published in Drink. Water Eng. Sci. Discuss.: 9 October 2009 \\ Revised: 5 January 2010 - Accepted: 7 January 2010 - Published: 13 January 2010
}

\begin{abstract}
The paper gives an overview of the methods for removal of natural organic matter (NOM) in water, particularly humic substances (HS), with focus on the Norwegian experiences. It is demonstrated that humic substances may be removed by a variety of methods, such as; molecular sieving through nanofiltration membranes, coagulation with subsequent floc separation (including granular media or membrane filtration), oxidation followed by biofiltration and sorption processes including chemisorption (ion exchange) and physical adsorption (activated carbon). All these processes are in use in Norway and the paper gives an overview of the operational experiences.
\end{abstract}

\section{Introduction}

NOM in water is a major concern and should be removed from drinking water for a number of reasons, including that NOM: a) affects organoleptic properties of water (colour, taste and odour); b) reacts with disinfectants used in water treatment, thus reducing their disinfection power; c) influences disinfectant demand and - process design, operation and maintenance; d) produces disinfection by-products (DBPs) of various kinds; e) affects stability and removal of inorganic particles; f) influences heavily on coagulant demand; g) may control coagulation conditions and coagulation performance; h) affects corrosion processes; i) affects biostability and biological regrowth in distribution systems; j) forms complexes with and increases mobility of chemical substances found in nature; $\mathrm{k}$ ) fouls membranes; 1 ) reduces adsorption capacity of granular or powdered activated carbon (GAC/PAC) by pore blocking, $\mathrm{m}$ ) competes with taste and odour compunds for adsorption sites in GAC/PAC (Eikebrokk et al., 2006).

The main NOM component in Norwegian water is attributed to humic substances (HS) that have several characteristics that influence on how NOM may be removed from water (Fabris et al., 2008; Eikebrokk et al., 2007):
1. Because of the large size of humic substance molecules (MW 1000-100 000), it is possible to separate HS directly from water by molecular sieving through a sufficiently tight membrane (nano-filtration).

2. Because the HS molecules are negatively charged at drinking water $\mathrm{pH}$, they can be coagulated, adsorbed to metal hydroxide and subsequently removed by floc separation.

3. Because of the negative charge, HS may be removed by chemical sorption (ion exchange). HS may also be adsorbed on activated carbon (physical adsorption).

4. Since the color of HS is associated with its aromatic content and $\mathrm{C}=\mathrm{C}$ bonds, the color can be removed by breaking these bonds through the addition of a strong oxidant.

5. Since HS is the end-point of nature's biodegradation, HS is close to being non-biodegradable. By use of a strong oxidising agent, however, the large HS molecules may be broken into smaller, biodegradable components, removable by biofiltration. 

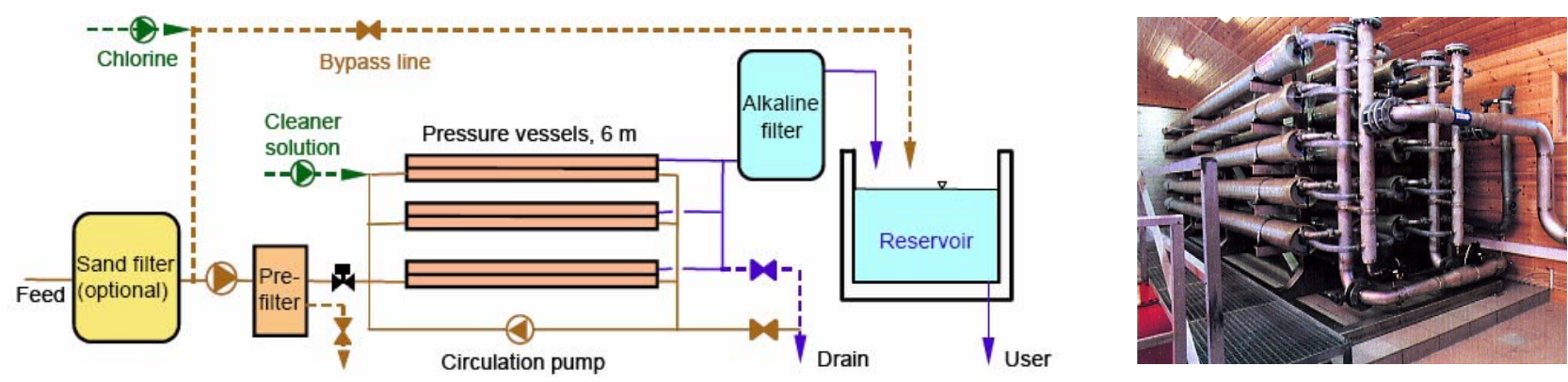

Figure 1. Typical flow diagram and picture of a nanofiltration plant for NOM removal.

Since the colour of the water is a major concern for users in Norway, emphasis will be given to colour ( $\mathrm{mg} \mathrm{Pt} / \mathrm{l})$ as a NOM characterization parameter in this paper. Typical relationships between colour, DOC and UV-absorption for the Norwegian raw waters referred to in this paper are:

$\operatorname{DOC}(\mathrm{mg} \mathrm{C} / \mathrm{l})=0.120$ Colour $(\mathrm{mg} \mathrm{Pt} / \mathrm{l})+1.0\left(R^{2}=0.935\right)$

DOC $(\mathrm{mg} \mathrm{C} / \mathrm{l})=0.241 \mathrm{UV}-$ abs. $(1 / \mathrm{m})+0.4\left(R^{2}=0.997\right)$

\section{Membrane (nano) filtration}

Research on membrane filtration (nano/ultra-filtration) for the removal of humic substances was started at the university in Trondheim around 1975 (Ødegaard and Kootatep, 1982) and the first full-scale plant was put into operation in 1990. Since then membrane filtration has become very popular in Norway and more than 100 nanofiltration (NF) plants are in operation at this time. Most of the plants are small, the largest plant having a design flow of $16000 \mathrm{~m}^{3} / \mathrm{d}$.

All the Norwegian NF plants are based on spiral wound modules and the majority on cellulose acetate (CA) membranes, with a few exceptions based on polyamide (PA) membranes. The typical pore size of the membranes is 1$5 \mathrm{~nm}(1000-2000 \mathrm{Da}$ ) operated at a pressure of 4-8 bar (Ødegaard et al., 2000). The typical flow diagram of a membrane filtration plant is shown in Fig. 1. The raw water passes first through a pre-treatment unit, normally a micro-sieve with a sieve opening of typically $50 \mu \mathrm{m}$. After the sieve, the pressure is raised up to the operating pressure of the membrane unit by a circulation pump. Cross-flow filtration takes place in the membrane unit resulting in a cleaned water stream (the permeate) that has passed through the membrane and a dirty water stream (the concentrate) that passes a reduction valve bringing the pressure in the concentrate back to that of the atmosphere. Some of the concentrate is recycled to the inlet in order to increase the recovery.

Since the reduction of calcium and bicarbonate concentration through the membrane filter is about $15-30 \%$, an alkaline filter (calcium carbonate) is often included in order to increase the level of calcium and bicarbonate in the typically soft and corrosive Norwegian water.
In order to prevent capacity reduction over time as a result of membrane fouling, the membranes cleaned by two different cleaning procedures: a frequent (daily) cleaning (chemical rinse) and a main cleaning that is carried out once or twice a year. In the daily cleaning, that normally lasts for about an hour and takes place during night, a chemical solution, also containing an oxidant (normally chlorine) for disinfection purposes, is pumped into the membrane module and circulated here for 20-30 min after which it is pumped out. Raw water is then lead through the membrane module for rinsing for $20-40 \mathrm{~min}$ before the plant is again put into operation. The plants are fully automated and the operator has only to see to that there are sufficient amounts of washing solutions and that the pressures in the plant are as intended. The main cleaning is normally carried out a couple of times per year coupled to a general service of the plant by the contractor. The washing chemicals may contain wetting agents (tensides, phosphates etc.), sequesters (phosphates, EDTA etc.), oxidation chemicals (peroxides, chlorine etc.) and enzymes (Ødegaard et al., 2000).

The NF process is often selected when the NOMcontent/color is high $(>30 \mathrm{mg} \mathrm{Pt} / \mathrm{l})$ and turbidity low $(<1 \mathrm{NTU})$. The most typical problems encountered are those connected to capacity loss caused by fouling. In most cases this is either caused by too high design flux relative to the characteristics of the water in question, especially too high flux for waters with high particle concentration and high NOM-content. Model calculations made by Thorsen (1999) indicated that particles in the size range of about $0.1-3 \mu \mathrm{m}$ are particularly critical for fouling. Thorsen and Fløgstad (2006) demonstrated when using a lab scale plant (flux 24 $\mathrm{L} / \mathrm{m}^{2} \mathrm{~h}$ ) on a colored surface water that the permeability decline was $31 \%$ over a $700 \mathrm{~h}$ period when using a $100 \mu \mathrm{m}$ prefilter before the spiral wound NF membrane and almost the same when using a $5 \mu \mathrm{m}$ prefilter, while it was close to $0 \%$ when using a $0.1 \mu \mathrm{m}$ prefilter. This demonstrates the importance of correct design relative to the water characteristics. Practical full-scale experiences show that the best spiral wound membranes can be operated for weeks with an almost constant flux up to $20 \mathrm{~L} / \mathrm{m}^{2} \mathrm{~h}$ (Thorsen and Fløgstad, 2006) and the design flux recommended is therefore in the range of 


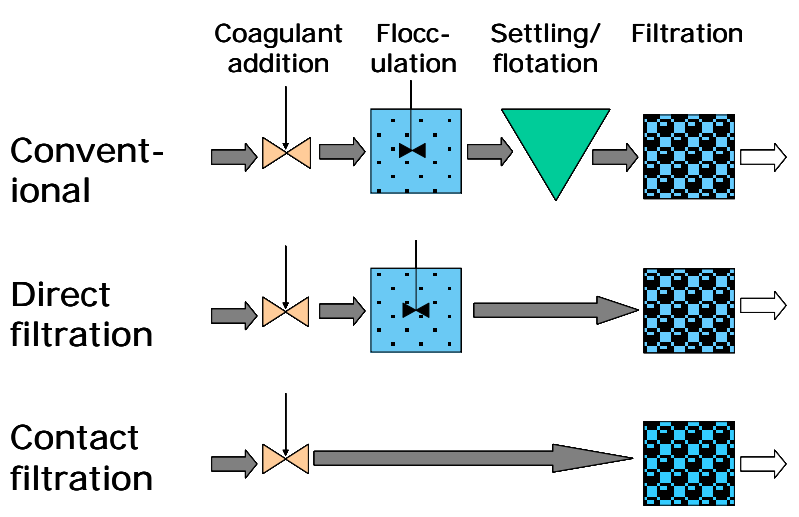

Figure 2. Coagulation/floc separation flow schemes.

$15-18 \mathrm{~L} / \mathrm{m}^{2} \mathrm{~h}$. The criteria for success in operating NF-plant for NOM-removal in Norway seem to be use of low flux $\left(\leq 20 \mathrm{~L} / \mathrm{m}^{2} \mathrm{~h}\right)$ combined with low recovery $(\leq 70 \%)$ and selection of CA-membranes (to avoid adsorptive fouling) with proper cleaning procedures (daily with a diluted solution to prevent a bound fouling layer combined with a more comprehensive chemical cleaning once or twice a year).

\section{Coagulation/filtration}

The conventional coagulation/floc separation method (see Fig. 2) is globally probably the most commonly used method for NOM substance removal. Principally it is constructed in a similar way as plants for turbidity removal. Since Norwegian lake water commonly is low in turbidity, the more compact flow diagrams (direct- or contact filtration), are dominating in Norway. The conventional process is used only when turbidity is higher than normal. Compact separation units (flotation and microsand ballasted lamella sedimentation) before the filter are favored when the conventional process is used.

Coagulation is normally carried out by the addition of aluminium sulfate, prepolymerised aluminium chloride of iron chloride as coagulants. The primary NOM-coagulation mechanisms are: a) complexation of NOM with dissolved metal coagulant species ( $\mathrm{Al}$ or $\mathrm{Fe}$ ), leading to direct precipitation of a Me-NOM solid phase, b) complexation of NOM with dissolved coagulant species, leading to adsorption of this complexed material onto precipitated $\mathrm{Me}(\mathrm{OH})_{3}$ solids, and c) direct adsorption of NOM onto the surface of precipitated $\mathrm{Me}(\mathrm{OH})_{3}$ solids. The coagulation of waters containing both particles and NOM becomes more complicated, involving several important factors: a) the dissolved coagulant species present upon coagulant addition, $b$ ) the presence of precipitated metal hydroxide solids, c) the concentration of particles and NOM, d) the chemical properties of these contaminants and their reactivity with dissolved coagulant species, and e) the $\mathrm{pH}$ of coagulation, which is affected by the chemistry of the coagulant and the water alkalinity (Eikebrokk et al., 2006).

The two most important factors in order to achieve optimal coagulation, flocculation and subsequent floc attachment and retainment on the filter grains, are the coagulant dosage and the coagulation $\mathrm{pH}$ (see Table 1).

Pre-polymerised aluminium chloride (PAX in Table 1) has the advantage of consuming less alkalinity than alum and is often preferred in the soft, low-alkalinity Norwegian waters. In most cases the most difficult water quality criteria to comply with, is the residual metal concentration after filtration (Eikebrokk, 2001). This has led to an increased use of iron based coagulants, especially in plants that use calcium carbonate as a filter media for corrosion control. The low optimum coagulation $\mathrm{pH}$ of ferric coagulants combines very well with the alkaline post-filtration because of the rapid dissolution of calcium carbonate (i.e. low contact time) and the supplementary removal of Fe-residuals in the alkaline filter bed.

The high molecular weight NOM fractions that are dominant in Norway are easier to coagulate than low molecular weight NOM. Since it is the high molecular weight fraction that contribute most to the color of the water, the color/DOCratio (or UV-absorption/DOC or SUVA-index) gives an indication of the dominating MW-factions in the water and consequently of the efficacy of coagulation. A color to DOC ratio higher than $5-10 \mathrm{mg} \mathrm{Pt} / \mathrm{mg} \mathrm{C}$ is considered favorable, and in such cases specific dosages in the range of 0.3 $0.6 \mathrm{mg} \mathrm{Al} / \mathrm{mg} \mathrm{C}$ or $0.03-0.06 \mathrm{mg} \mathrm{Al} / \mathrm{mg} \mathrm{Pt}$, are typical (Eikebrokk, 2001).

Cationic, synthetic polymers (Bolto et al., 1998; Kvinnesland and Ødegaard, 2004) can also be used for NOMcoagulation but there is no tradition for this in Norway. However, the cationic biopolymer chitosan is used for coagulation to some extent. Chitosan can remove color reasonably well, but it is not comparable to metal coagulants with respect to DOC removal. The main advantages are related to the ease of sludge handling (biodegradable and non-toxic) and the nonexisting residual metal problem. Chitosan can be used alone or in combination with a metal coagulant. In contact flocculation plants a non-ionic or anionic synthetic polymer is often used to enhance flocculation and increase filter run lengths.

Sub-optimal coagulation conditions ( $\mathrm{pH}$ and dosage) represent various operational challenges for the whole plant as such. First of all it may lead to too high residual metal content as well as reduced filtrate quality levels (NOM, turbidity, pathogens etc.), but sub-optimal conditions impact on the filter performance as well. Too high coagulant dosage, for instance, may lead to: a) short filter runs (early breakthroughs, head loss), b) reduced alkalinity/increased base consumption, c) increased sludge production (metal hydroxide), d) increased backwash water consumption and e) increased operation costs. Eikebrokk et al. $(2006,2007)$ developed several empirical models for the purpose of optimization of operation performance in Norwegian contact filtration plants: 
Table 1. Recommended $\mathrm{pH}$ and dose using alum (ALG), iron (JKL) or chitosan (Chi) in contact filtration of raw waters at color levels of 15, 30 and $50 \mathrm{mg} \mathrm{Pt} / \mathrm{L}$ (Eikebrokk, 2001).

\begin{tabular}{cccccc}
\hline Raw water colour & $\begin{array}{c}\text { Raw water SUVA } \\
\text { L/mg C m }\end{array}$ & \multicolumn{4}{c}{$\begin{array}{c}\text { Recommended specific coagulant dosage and } \\
\text { pH mmol Me or mmol Chi/gTOC; ( } \mu \text { g Me or } \mu g \text { Chi/mgPt) }\end{array}$} \\
& ALG pH 5.8-6.6 & JKL pH 4.0-5.5 & PAX pH 5.7-6.7 & CHI pH 5.0-6.0 \\
\hline RW15 & 3.8 & $16(78)$ & $16(162)$ & $14(67)$ & $0.6(110)$ \\
RW30 & 4.3 & $20(63)$ & $20(128)$ & $17(54)$ & $0.7(80)$ \\
RW50 & 4.8 & $26(61)$ & $26(100)$ & $20(49)$ & $0.8(70)$ \\
\hline
\end{tabular}

ALG-aluminium sulphate, JKL-ferric chloride; PAX-poly aluminium chloride; Chi-Chitosan.

For Me-coagulants: Dose levels needed to obtain $<0.1 \mathrm{mg}$ residual $\mathrm{Me} / \mathrm{L},>90 \%$ and $50-60 \%$ colour and TOC reduction Absolute minimum doses are $25 \%$ lower than the given practical minimum doses.

For Chitosan: Dose levels needed to obtain $>60 \%$ and $20-35 \%$ colour and TOC reduction, resp.

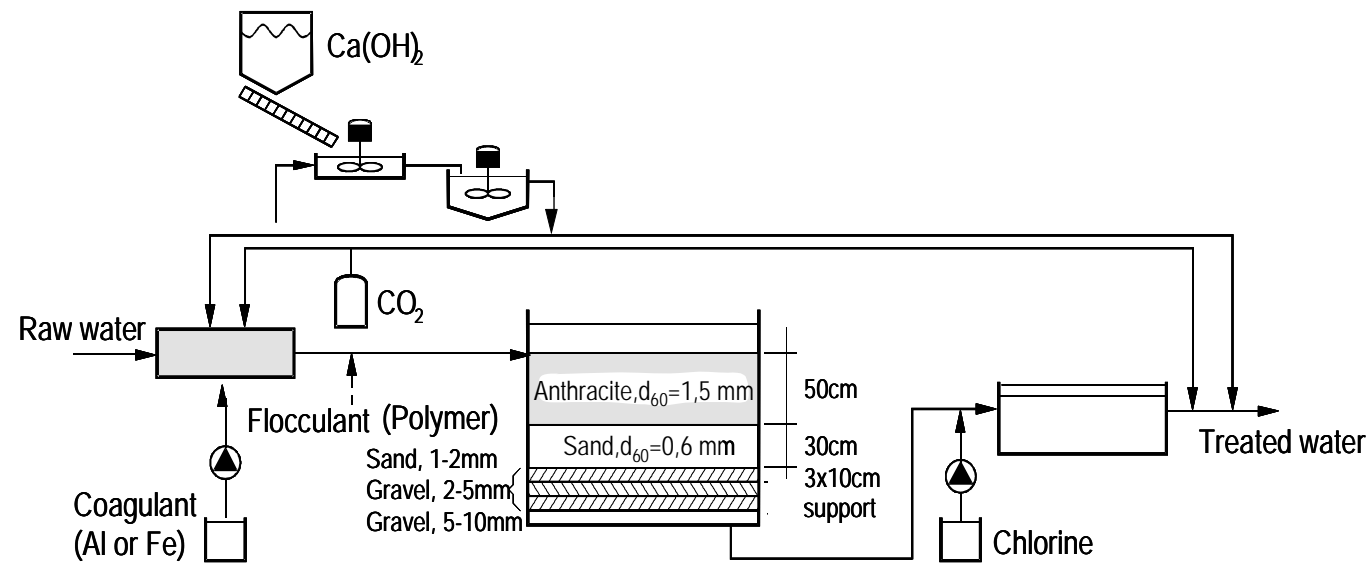

Figure 3. Typical flow scheme for a contact filtration plant for NOM removal in Norway.

Minimum required coagulant dose: Dose $(\mathrm{mg} \mathrm{Me} / \mathrm{L})=A$. Raw water Colour $(\mathrm{mg} \mathrm{Pt} / \mathrm{L})+B$ where $A$ and $B$ are constants depending on the coagulant and operational conditions. For alum $A$ was found to be 0.043 and for iron 0.107 , while $B$ was found to be 0.30 for alum and 0.58 for iron. The practical minimum dose was recommended to be $25 \%$ higher than this.

Sludge production at optimum coagulation: SS $(\mathrm{mg} / \mathrm{L})=\mathrm{SS}_{\mathrm{RW}}+k \cdot$ Dose where $\mathrm{SS}_{\mathrm{RW}}$ is the suspended solid concentration in the raw water including the contribution from additional processes like $\mathrm{pH}$ - and corrosion control, $k$ is a constant depending on the type of coagulant and Dose is the coagulant dose (mg Me/L). For alum and ferric chloride as coagulant, $k$ is found to be 4.2 and 2.5 respectively

Filter run time to break through at optimum coagulation: $t_{\mathrm{BT}}=a\left(v_{\mathrm{f}} \cdot \mathrm{SS}\right)^{b}$ where $t_{\mathrm{BT}}$ is time of filtration until breakthrough (h), $v_{\mathrm{f}}$ is rate of filtration $(\mathrm{m} / \mathrm{hr}), \mathrm{SS}$ is the suspended solids concentration in coagulated water, i.e. sludge production ( $\mathrm{mg} \mathrm{SS} / \mathrm{L}$ ), and $\mathrm{a}$ and $\mathrm{b}$ are constants specific to the filter and coagulant. For alum without any polymer as filter aid and $\mathrm{SS}_{\mathrm{RW}}=0$, the time of filtration has been found to be: $t_{\mathrm{BT}}=298\left(v_{\mathrm{f}} \cdot \text { Dose }_{\mathrm{Al}}\right)^{-1.29}$.

\subsection{Alternative filter configurations}

The two-media anthracite/sand filter is most commonly used filter configuration, as shown in Fig. 3. An alternative twomedia configuration is the one based on, Filtralite (Fig. 4), a lightweight expanded clay media produced in Norway. By using Filtralite of two different grain sizes and densities, a coarse-to-fine media filter is established.

Saltnes et al. $(2001,2002)$ demonstrated in a Filtralite filter with coarse grains (see Fig. 4) and consequently high sludge storage capacity/long filter runs, that bigger grain sizes could be compensated for by increasing filter depth, especially when using a polymer as filter aid.

Because of the need for corrosion control, an alternative filter configuration has become popular in Norway, where calcium carbonate is used as the bottom media in a downflow three media filter with conventional anthracite/sand as the upper media (Fig. 5) (Ødegaard, et al., 1999). Floc separation takes place in the anthracite/sand part of the filter while the calcium carbonate part has the function of carbonation. Most of these plants use iron chloride as coagulant (typical 


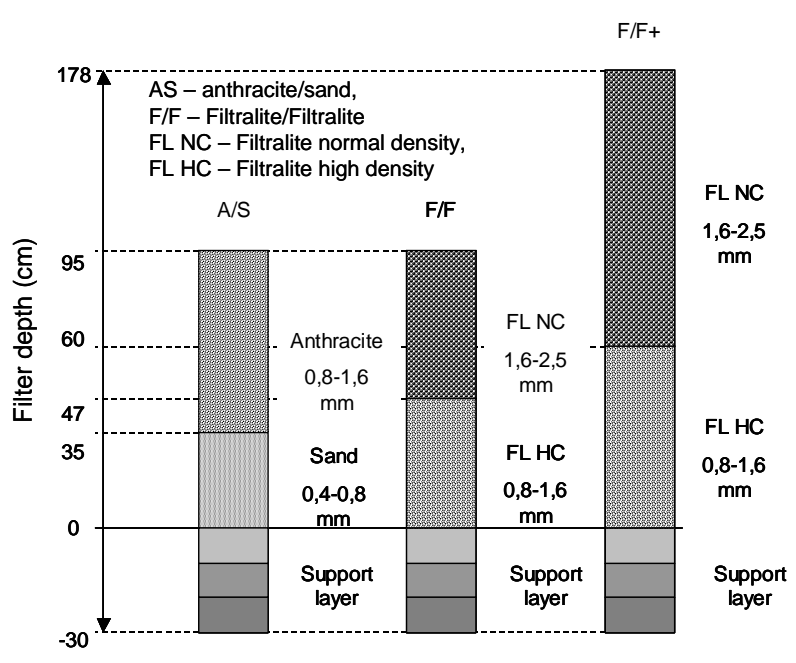

Figure 4. The mono-multi Filtralite filter.

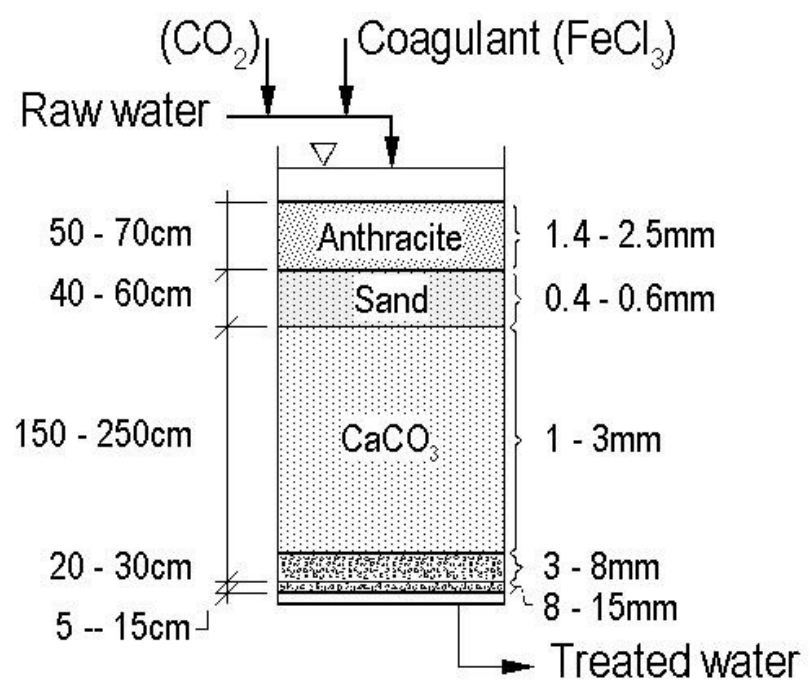

Figure 5. The three media filter for coagulation/carbonatisation.

dosage 3.3-5 mg Fe/l) in order to reach the operating $\mathrm{pH}$ of $3.5-4.0$ that is required to ensure sufficient dissolution of the $\mathrm{CaCO}_{3}$. In some of these plants $\mathrm{CO}_{2}$ is added as well (typically $6-15 \mathrm{mg} / \mathrm{l}$ ) in order to minimize the iron dosage. $\mathrm{pH}$, grain size as well as contact time influence the dissolution of the marble in order to arrive at the combination of $\mathrm{pH}$, alkalinity and Ca-concentration aimed for (see above). In a typical Norwegian situation, it is experienced that the empty bed contact time in the marble part of the filter should be at least 15-25 min. A filter depth of the marble layer of 150 $250 \mathrm{~mm}$ at a filtration rate of $5 \mathrm{~m} / \mathrm{h}$ is required (see Fig. 5). After reaching a critical lower grain size, the smallest grains are washed out during back-washing and new marble grains have to be supplied. New grains are supplied during back-

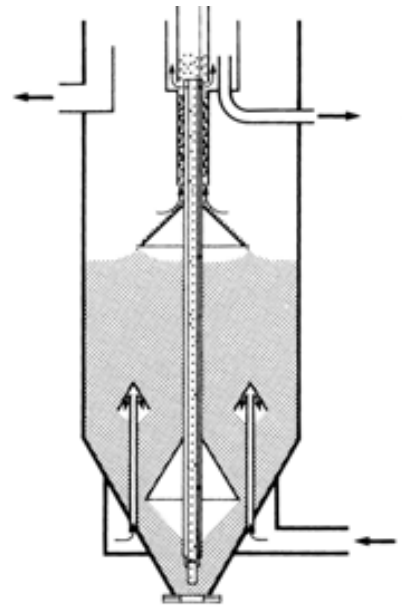

Figure 6. The continuous, uplow (Dynasand) filter.

washing in order to ensure the proper grain grading at the start of a new filtration cycle. In the three media filters a typical back-washing routine is composed of 3 min water backwash at $60-80 \mathrm{~m} / \mathrm{h}, 3 \mathrm{~min}$ backwash with air (together with water) and finally $6.5 \mathrm{~min}$ water backwash. Overall this results in quite high backwash water consumption, in the range of 6-11\% (Ødegaard et al., 1999).

Another filter that is much used in Norway in contact filtration plants for NOM-removal is the continuously operated filter - the so-called Dynasand filter (see Fig. 6).

\subsection{Coagulation/membrane filtration}

There is now an increasing interest in replacing the granular media filtration after coagulation with membrane (ultra- or micro-) filtration. At this time only one full scale plant based on coagulation (poly aluminium chloride)/hollow fibre UF $(10 \mathrm{~nm})$ membrane filtration (Xiga, Norit) is in operation in Norway. It has a stable operation at a flux of $80 \mathrm{~L} / \mathrm{m}^{2} \mathrm{~h}$ at $90 \%$ recovery on a raw water with color $40 \mathrm{mg} \mathrm{Pt} / \mathrm{L}$. The plant is backwashed with treated (and chlorinated) water and chemical cleaning (75\% phosphoric acid, soaking for $20 \mathrm{~min}$ and $15 \%$ sodium hypochlorite, soaking for $15 \mathrm{~min}$ ) is performed every 8 th backwash.

Research is being carried out at Norwegian University of Science and Technology (NTNU) both on ultra- and microfiltration. Two systems have been investigated for NOM removal:

1. A system based on coagulation, flocculation and submerged, hollow fibre, outside-in UF filtration (Zenon Zeeweed) (Machenbach and Ødegaard, 2004).

2. A system based on coagulation, flocculation and insideout ceramic microfiltration membranes (Metawater) (Meyn et al., 2007). 
In both cases a water with a high color $(50 \mathrm{mg} \mathrm{Pt} / \mathrm{L}$ corresponding to a TOC of $5.5 \mathrm{mg} / \mathrm{l}$ ) has been investigated. It has been shown that the optimized coagulation ( $\mathrm{pH}$ and coagulant dose) conditions for membrane filtration are pretty much the same as for sand filtration. In the UF study (Machenbach and Ødegaard, 2004), that was carried out with operating fluxes in the range of $45-75 \mathrm{~L} / \mathrm{m}^{2} \mathrm{~h}$, it was demonstrated that optimization of floc aggregation (flocculation) was important in order to minimize trans-membrane pressure (TMP) build-up. A packed bed flocculator at low velocity gradients (G-value $\leq 30 \mathrm{~s}^{-1}$ ) and $\geq 5$ min empty bed residence time gave lower TMP-build-up than a high velocity gradient (G-value $\simeq 400 \mathrm{~s}^{-1}$ ) and $30 \mathrm{~s}$ residence time pipe flocculator. In the MF study, however, that was operated at fluxes in the range of $140-220 \mathrm{~L} / \mathrm{m}^{2} \mathrm{~h}$, a pipe flocculator operated at varying conditions ( $\mathrm{G}=60$ and $300 \mathrm{~s}^{-1}$ and HRT 7.5 and $\left.30 \mathrm{~s}\right)$ gave only moderately higher TMP build-up than the standard, traditional two-stage flocculation tank with 20 min HRT (Meyn et al., 2007). The difference in experience is probably caused by the fact that conditions suitable for good flocculation exist inside the ceramic membrane module itself.

The higher flux of the MF-unit was not sustainable and it seems that the recommended fluxes for UF-membranes after coagulation of NOM is typically $50-70 \mathrm{~L} / \mathrm{m}^{2} \mathrm{~h}$ while it is the range of $130-160 \mathrm{~L} / \mathrm{m}^{2} \mathrm{~h}$ in MF membranes.

\section{Oxidation/biofiltration}

\subsection{Oxidation}

In humic surface water where color removal and disinfection is the main target, ozonation normally is the preferred oxidation method. The oxidation of NOM by ozone can follow two main pathways; 1) direct oxidation by ozon which selectively targets mainly activated aromatics and double bonds, and 2) indirect reaction where ozone is decomposed to form hydroxyl radicals which are more powerful but less selective oxidants than ozone. Consequently, the direct reaction pathway results in high color removal, but little TOC removal, whereas the indirect pathway removes less color and more TOC. The water matrix may determine the importance of the two pathways, and also the degree of scavenging. $\mathrm{pH}$ is of particular importance, and at high $\mathrm{pH}$ the indirect reaction pathway dominates and the ozonation may be considered as an AOP (Advanced Oxidation Process, defined as using hydroxyl radicals for oxidation). The use of an AOP may be advantageous if oxidation of ozone resistant compounds is desired (i.e. several micro-pollutants, atrazine, alachlor, etc.). A disadvantage of the AOP's is that the hydroxyl radicals are very unstable, easily scavenged and have a very short lifetime. Ozonation may become an AOP when combined with $\mathrm{H}_{2} \mathrm{O}_{2}$ or UV, or by using a catalytic packing media in the ozone column. Other AOP's may also be applied, such as $\mathrm{UV} / \mathrm{H}_{2} \mathrm{O}_{2}, \mathrm{UV} / \mathrm{TiO}_{2}$, Vacuum-UV, Fenton, etc.

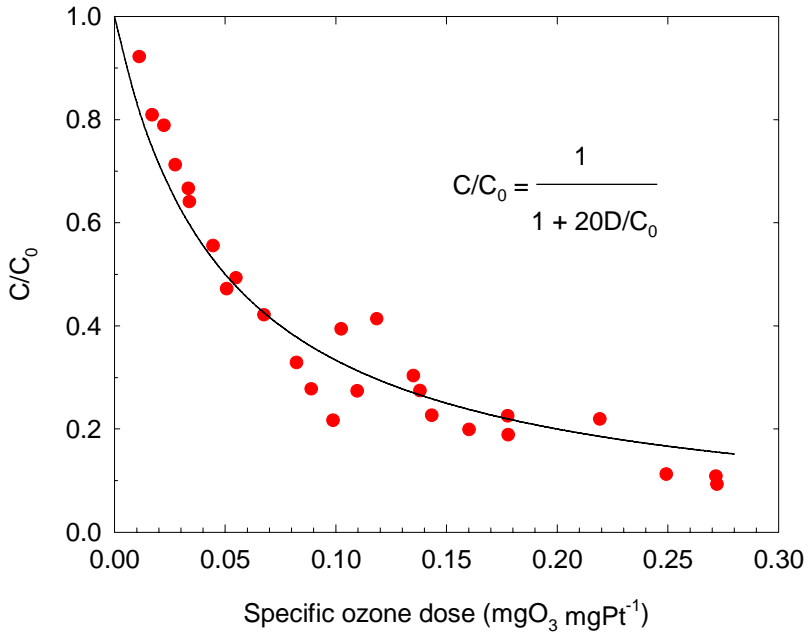

Figure 7. Color reduction versus specific ozon dose.

When using ozonation in humic surface water without any pollutants, the direct oxidation reaction pathway is advantageous. This would imply that using an inert ozone column packing media is beneficial and that the $\mathrm{pH}$ should be neutral to low. At high alkalinity and NOM concentration the efficiency of the system would be somewhat reduced,

In practice the ozone dose required for $80 \%$ colour removal that has typically been achieved in pilot- and full-scale plants, is around $0.15-0.20 \mathrm{mg} \mathrm{O}_{3} / \mathrm{mgPt}$ which translates to 1.0-1.5 mg O $3 / \mathrm{mgTOC}$, see Fig. 7 (Ødegaard et al., 2006).

\subsection{Ozonation/biofiltration}

Ozonation is effective in colour removal from humic surface water - see Fig. 7 in which the colour removal versus specific dose is shown for different waters (Ødegaard er at, 2006).

Ozonation of colored water, however, also results in reaction products that are far more biodegradable than the original humic substances. Biofiltration is therefore required in order to remove the easily biodegradable organic ozonation by-products. The flow-scheme of various alternatives of an ozonation/biofiltration plant is shown in Fig. 8.

It is well known that activated carbon filters after ozonation of NOM-containing waters results in biological activity in the filter. The run-time of GAC filters is increased because of "biological regeneration". In Norway we have also experiences from plants with biofilters consisting of packed bed plastic carrier (Kaldnes K1) followed by sand filters for biomass separation, combined biofilters/separation filters with Filtralite or with three-media (anthracite/sand/calcium carbonate) as filter medium (Melin et al., 2006). Besides the fact that granular activated carbon (GAC) filters give a quicker start-up caused by the adsorption effect, the rate of biodegradation does not seem to be strongly influenced by the media selected, while the kinetic studies show that 


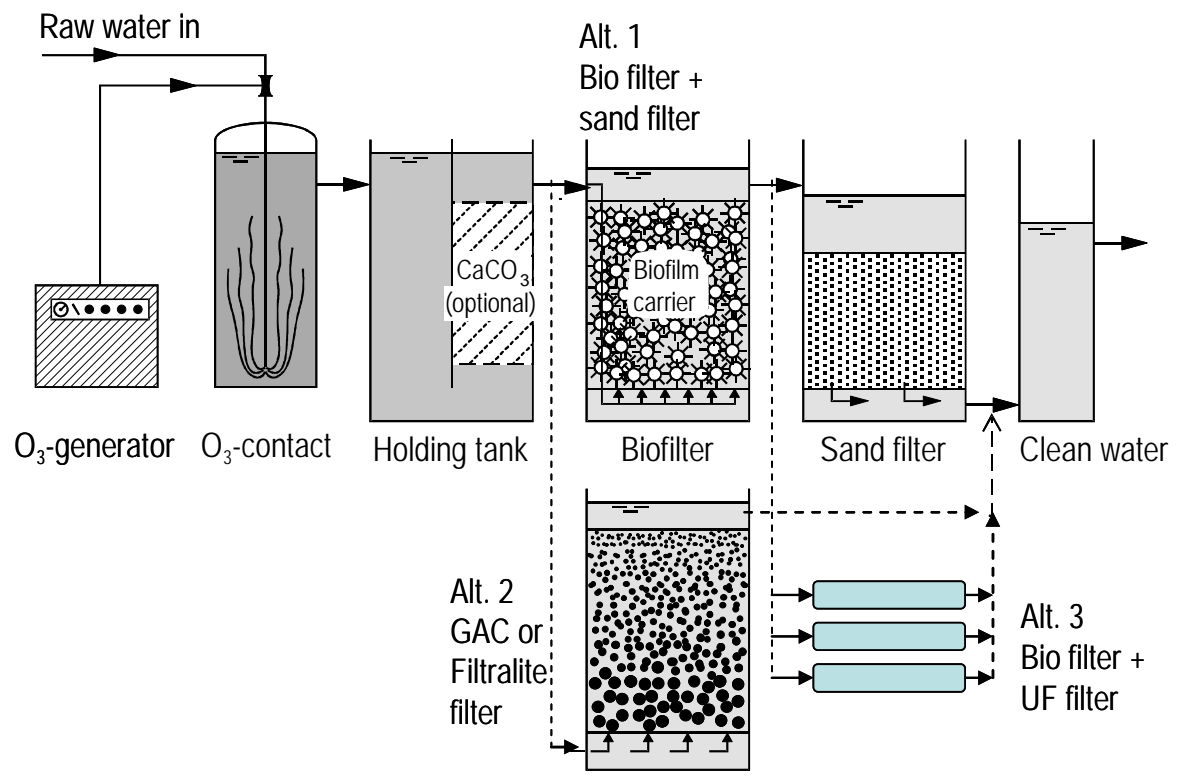

Figure 8. Alternative flow diagrams for ozonation/biofiltration plants.

residence time is of importance. The results show that for typical Norwegian water, the EBCT should not be less than around 20 min (Ødegaard and Melin, 2006). The total TOC removal is relatively low, typically in the range of $20-30 \%$ even through the color removal is high (70-80\%) at ozone dosages mentioned above (Melin and Ødegaard, 2000). The oxidation method is, therefore, not suitable for raw waters with high NOM-content, but for waters with an average color around $30 \mathrm{mg} \mathrm{Pt} / \mathrm{l}$, which is quite common in Norway, the experiences with the method are quite satisfactory. It is a very simple process to operate without any external chemicals needed and it gives a good hygienic barrier ( $>3 \log$ reduction of bacteria and virus and $>2 \log$ reduction of Giarda) because of the high ozone concentration

\subsection{The OBM-process}

In the European project TECHNEAU our group has investigated an oxidation/biofiltration/ membrane filtration process (OBM-process) that is based on the "multi-barrier" concept (Azrague et al., 2009). The process is comprised of three separate independent processes.

1. The first step is oxidation, based on ozonation or an advanced oxidation process $\left(\mathrm{AOP}-\mathrm{O}_{3} / \mathrm{H}_{2} \mathrm{O}_{2}, \mathrm{UV} / \mathrm{TiO}_{2}\right.$ etc.). It will in addition to be a 1 . hygienic barrier, also result in a) NOM-oxidation (color removal), b) oxidation of trace organics, c) oxidation and improvement of taste and odor and d) oxidation of inorganics ( $\mathrm{Fe}, \mathrm{Mn}$ etc.).
2. The second step (biofiltration) will improve the biostability of the water by removing the easiest biodegradable organic matter produced by the oxidation step.

3. The third step, membrane filtration (MF, UF or NF) is there to remove a) biomass produced in the second step, b) oxidized/precipitated inorganics and c) pathogen microorganisms (constituting another hygienic barrier).

In a pilot plant operated at the university (NTNU), it has been demonstrated (Østerhus and Azrague, 2009), that the OBM process achieved good colour removal (>80\%) during ozonation even in high NOM water. After the biofiltration stage the produced water was bio-stable, with a very low sludge production in the biodegradation stage.

Final separation by ultrafiltration using polymeric membranes in an immersed configuration (Zenon, ZeeWeed) worked very well as it could be operated at high fluxes $\left(801 / \mathrm{m}^{2} \mathrm{~h}\right)$, with a high recovery $(98 \%)$, still permitting operational time of approximately $400 \mathrm{~h}$ before chemical cleaning was needed (approx. $600 \mathrm{~h}$ of operation at a flux of $60 \mathrm{l} / \mathrm{m}^{2} \mathrm{~h}$ ). By modifying the operation mode (air scouring) and reactor design, the process can probably be further optimized. The use of ceramic microfiltration membranes (Metawater) for the final separation on the other hand caused severe fouling. This may be because the MF membrane is more prone to pore blockage due to submicron particles coming from the biofilter.

The OBM process is suitable for medium to low NOM containing water (20-40 mg Pt/l), and acts as an efficient hygienic barrier process producing high quality water. It has shown to be very robust and flexible, and it may be designed 
for removal of several micro pollutants. The cost estimation has shown that the OBM process is competitive with conventional treatment processes (Azrague et al., 2009).

\section{Sorption processes}

GAC adsorption as well as ion exchange may be used for removing humic substances.

\subsection{GAC adsorption}

Direct activated carbon adsorption is not recommendable since the sorption capacity is quickly reduced by pore blocking caused by the large HS molecules (Kaastrup and Halmo, 1989). GAC adsorption of NOM may be suitable as posttreatment for other processes (coagulation, ozonation etc.) that have removed or changed the HS-molecules to the extent that the residuals may be sufficiently small to arrive at sites in the finer pores. GAC is not used as the only NOMremoving process in Norway, but is used as filter medium in ozonation/biofiltration plants.

\subsection{Chemisorption (ion exchange)}

Humic substances may be removed by macroporous anion exchangers because of the negative charge of the humic molecules at normal $\mathrm{pH}$. The raw water is pre-treated in a micro-sieve (pore opening $50 \mu \mathrm{m}$ ) or a rapid sand filter when the turbidity is higher than $0.5-1.0$ FTU. Thereafter, the water is passed through ion exchange filters placed in parallel or in series. The process is only used in small plants in Norway in which only two ion exchange filters are used that normally are operated in series even though parallel operation is also possible.

An empirical model for the break-through curve as a function of raw water concentration $C_{0}$ (UV-ext., $\mathrm{m}^{-1}$ ), empty bed contact time, $t_{k}$ (min) and filter run time, $t(\mathrm{~h})$ and temperature, $T\left({ }^{\circ} \mathrm{C}\right.$ ) has been developed (Ødegaard et al., 1989):

$C / C_{0}=0.04 \cdot C_{0}^{0.46} \cdot t_{k}^{-0.67} \cdot t^{0.37} \cdot T^{0.13}$

The contact time is a more relevant parameter than the filter velocity. Typically a contact time of at least $10 \mathrm{~min}$ at maximum flow is used when the goal is to bring the colour down to less than $10 \mathrm{mg} \mathrm{Pt} / \mathrm{l}$. If a lower treated-water colour is aimed for, a longer contact time will have to be used. Typically a bed depth (h) of $0.5-2 \mathrm{~m}$ is used resulting in filtration rates of $v_{f}=h n 60 / t_{k}$ where $n$ is the number of columns in series and $t_{k}$ is contact time. It is recommended that the filter rate at design load does not exceed $20 \mathrm{~m} / \mathrm{h}$.

After breakthrough the ion exchanger has to be backwashed and regenerated. Normally an alkaline salt solution $(2 \% \mathrm{NaOH}+10 \% \mathrm{NaCl})$ is used. While the flow during normal operation is downwards, the flow during backwash is upwards while the flow during regeneration may either be downwards or upwards. The regeneration solution is typically reused 7-8 times and in such a manner that about $1 / 8$ of the regeneration solution volume is substituted after each regeneration.

Until now, the magnetic ion exchange process (MIEX) is not applied at Norwegian water treatment plants.

\section{Conclusions}

Natural organic matter (NOM - with its main constituent humic substances), has several negative influences in water that is to be used for water supply and needs therefore to be removed. The characteristics of humic substances (MW, charge, hydrophobic and, aromatic nature etc.) give the opportunity of several removal methods:

1. Because of the large molecular size NOM may be removed by molecular sieving, i.e. filtration through NF membranes. According to the Norwegian experiences, predominantly with cellulose acetate membranes (typically $3 \mathrm{~nm}$ effective pore size), the plants should be designed for a moderate flux ( $<20 \mathrm{LMH})$ and recovery $(<70 \%)$ and operated with daily light cleaning for fouling control. NF is suitable when the NOM concentration and color is high.

2. Because of the charge and colloidal nature, NOM can be removed by coagulation and floc separation. Coagulant dose and $\mathrm{pH}$ of coagulation are the two most important factors for achieving optimal treatment result. In most cases, the maximum residual metal concentration level $(0.15 \mathrm{mg} \mathrm{Me} / \mathrm{L})$ determines the required coagulant dose level. Contact filtration is often used for raw water color levels up to about $50 \mathrm{mg} \mathrm{Pt} / \mathrm{L}$ and turbidity levels less than 1-2 NTU. Above this a pre-separation step (settling/flotation) is recommended.

3. The color of NOM may effectively be removed by ozonation (or another strong oxidative method). Oxidation has to be proceeded by biofiltration in order to lower the growth potential of the water. Typical $\mathrm{O}_{3}$-dosages are $0.15-0.20 \mathrm{mg} \mathrm{O}_{3} / \mathrm{mg} \mathrm{Pt}$ or $1-$ $1.5 \mathrm{mg} \mathrm{O}_{3} / \mathrm{mg}$ TOC. Necessary biofilter EBCT is around 20-30 min. Ozonation/ biofiltration is recommended for relatively low color levels, typically below $35 \mathrm{mg} \mathrm{Pt} / 1$. Otherwise the biogrowth potential created by the ozonation may be too high for the biofilter to handle.

4. Sorption processes are less used for NOM removal. GAC adsorption as the only process is unsuitable because of pore blocking resulting in low capacity and short filter runs. GAC may, however, be suitable in combination with pre-ozonation. Ion exchange (based on macroporous anion exchangers) is used in small plants, but is only recommended for relatively low raw water color levels, typically below $30 \mathrm{mg} \mathrm{Pt} / \mathrm{l}$. 
Edited by: B. Heijman

\section{References}

Azrague, K., Østerhus, S. W., and Leiknes, T.: Assessment of the OBM-process for drinking water treatment, Proc. Int. Wisa Membrane Technology Conference 2009, Stellenbosch, SouthAfrica, 13-15 May 2009.

Bolto, B. A., Dixon, D. R., Eldridge, R. J., and King, S. J.: The use of cationic polymers as primary coagulants in water treatment, in: Chemical water and wastewater treatment V, edited by: Hahn, H. H., Hoffmann, E., and Ødegaard, H., Springer Verlag, Berlin Heidelberg, 173-185, 1998.

Eikebrokk, B.: Removal of humic substances by coagulation, in: Chemical water and wastewater treatment V, edited by: Hahn, H. H., Hoffmann, E., and Ødegaard, H., Springer Verlag, Berlin Heidelberg, 173-187, 1996.

Eikebrokk, B.: Aspects of enhanced coagulation-contact filtration process optimisation, Proc. Workshop on utilization of NOM characteristics to improve process selection and performance. AWWARF, Vivendi Water, CRC for Water Quality and Treatment, Berlin Germany, 9-12 Oct 2001.

Eikebrokk, B., Juhna, T., and Østerhus, S. W.: Water treatment by enhanced coagulation - Operational status and optimization issues, Techneau, D 5.3.1, http://www.techneau.eu, December 2006.

Eikebrokk, B., Juhna, T., Melin, E., and Østerhus, S. W.: Water treatment by enhanced coagulation and oxonation-biofiltration: Intermediate report on operation optimization procedusre and trielas, Techneau, D 5.3.2A, http://www.techneau.eu, December 2007.

Eikebrokk, B., Fabris, R., Drikas, M., and Chow, C.: NOM Characteristics and Treatability by Coagulation, in: Chemical Water and Wastewater Treatment IX, edited by: Hahn, H. H., Hoffman, E., and Ødegaard, H., IWA Publishing, London, 207-219, 2007.

Fabris, R., Chow, C. W. K., Drikas, M., and Eikebrokk, B.: Comparison of NOM character in selected Australian and Norwegain drinking waters, Water Res., 42, 4188-4196, 2008.

Fløgstad, H. and Ødegaard, H.: Treatment of humic waters by ozone, Ozone Science and Engineering, 7, 121-136, 1985.

Thorsen, T. and Fløgstad, H.: Nanofiltration in drinking water treatment, Literature review, Techneau, D 5.3.4B, http://www. techneau.eu, December 2006.

Thorsen, T.: Fundamental studies on membrane filtration of coloured surface water, Dr-thesis, Norwegian University of Science and Technology (NTNU), November 1999.

Kaastrup, E. and Halmo, T.: Removal of aquatic humus by ozonation and activated-carbon adsorption, Chapter 39, in: Suffet and MacCarthy: Aquatic Humic Substances. Influence on Fate and Treatment of Pollutants, Advances in Chemistry Series 219, American Chemical Society, 1989.

Kvinnesland, T. and Ødegaard, H.: The effects of polymer charachteristics on nano particle separation in humic substance removal by cationic polymer coagulation, Wat. Sci. Tech., 50, 12, 185191, 2004.
Machenbach, I. and Ødegaard, H.: Relevance of flocculation in integrated membrane processes for NOM removal, in: Chemical water and wastewater treatment VII, edited by: Hahn, H. H., Hoffmann, E., and Ødegaard, H., IWA Publishing, London, 245254, 2004.

Melin, E., Skog, R., and Ødegaard, H.: Ozonation/biofiltration with calcium carbonate as biofilter media, in: Recent Progress in Slow Sand and Alternative Biofiltration Processes, edited by: Gimbel, R., Graham, N. J. D., and Colllins, M. R., IWA Publishing 2006, 406-413, ISBN 9781843391203, 2006.

Melin, E. and Ødegaard, H.: The effect of biofilter loading rate on the removal of organic ozonation by-products, Water Res., 34, 18, 4464-4476, 2000.

Meyn, T., Leiknes, T., and Ødegaard, H.: Coagulation/flocculation - ceramic membrane filtration for removal of natural organic matter (NOM) under Norwegian conditions, Proc. IWA Conference on Membranes for Water and Wastewater treatment, Harrogate, UK, 15-17 May 2007.

Saltnes, T., Eikebrokk, B., and Ødegaard, H.: Contact Filtration of Humic Waters, performance of an expanded clay aggregate filter (Filtralite) compared to a dual anthracite/sand Filter, Water Science and Technology: Water Supply, 2, 5-6, 2002.

Saltnes, T., Eikebrokk, B., and Ødegaard, H.: Coagulation optimization for NOM removal by direct filtration in clay aggregate filters, Water Supply: Research and technology - AQUA, 51, 2, 125-134, 2001.

Ødegaard, H. and Koottatep, S.: Removal of humic substances from natural waters by reverse osmosis, Water Res., 16, 613-620, 1982.

Ødegaard, H., Brattebø, H., and Halle, O.: Removal of humic substances by ion exchange, Chapter 45, in: Suffet and MacCarthy: Aquatic Humic Substances. Influence on fate and Treatment of Pollutants, Advances in Chemistry Series 219, American Chemical Society, 1989.

Ødegaard, H. and Thorsen, T.: Removal of humic substances by membrane processes, Chapter 42, in: Suffet and MacCarthy: Aquatic Humic Substances. Influence on Fate and Treatment of Pollutants, Advances in Chemistry Series 219, American Chemical Society, 1989.

Ødegaard, H., Eikebrokk, B., and Storhaug, R.: Processes for the removal of humic substances from water - An overview based on Norwegian experiences, Wat. Sci. Tech., 40(9), 37-46, 1999.

Ødegaard, H., Thorsen, T., and Melin, E.: Practical experiences from membrane filtration plants for humic substance removal, Wat. Sci.Tech., 41, 10-11, 33-41, 2000.

Ødegaard, H., Melin, E., and Leiknes, T.: Ozonation/biofiltration for treatment of humic surface water, in: Recent Progress in Slow Sand and Alternative Biofiltration Processes, edited by: Gimbel, R., Graham, N. J. D., and Collins, M. R., IWA Publishing, 397405, ISBN 9781843391203, 2006.

Østerhus, S. W. and Azrague, K.: Removal of NOM by an Oxidation-Biofiltration-Membrane filtration (OBM) process, Organic Geochemistry, submitted, 2009. 